\title{
36. SEISMIC VELOCITIES, DENSITIES, AND ELASTIC CONSTANTS AT ELEVATED PRESSURES OF BASALTS AND VOLCANICLASTIC BRECCIAS, DSDP LEG 43
}

\author{
Nikolas I. Christensen, Joe M. Hull, and Kathleen A. Hubert, Department of Geological Sciences, University of \\ Washington, Seattle, Washington
}

\section{INTRODUCTION}

Laboratory investigations of velocities in dredged and drilled oceanic rocks have proven valuable in understanding the influences of geologic processes such as fracturing and weathering on upper crustal seismic velocities (e.g., Barrett and Aumento, 1970; Christensen and Shaw, 1970; Christensen and Salisbury, 1973; Fox et al., 1973). However, because basalts constitute the preponderance of basement rocks recovered by the Deep Sea Drilling Project, very little information exists on velocities of other rock types which may be important constituents of the upper oceanic crust. Thus, the rocks obtained on Leg 43 are particularly significant because well-consolidated volcaniclastic breccias were recovered from two sites drilled near seamounts. In this paper, we report velocities and densities of these breccias and compare these data with similar data from oceanic basalts.

\section{DATA}

The pulse transmission technique, similar to that described by Birch (1960), was used for measuring velocities. Compressional and shear waves were generated by $1 \mathrm{MHz}$ barium titanate and $\mathrm{A}-\mathrm{C}$ cut quartz transducers, respectively, and first arrivals were compared with arrivals from a variable length mercury delay line. Hydrostatic pressure was measured to \pm 1 per cent by a calibrated manganin coil, and the accuracies of the velocities are estimated at \pm 1 per cent (Birch, 1960; Christensen and Shaw, 1970). Bulk densities of the cylindrical samples were calculated from volumes and dry weights. The samples were then saturated with water to simulate in situ conditions. Pore pressures were maintained at a minimum by placing 100 mesh screens between the samples and copper jackets.

The velocity data and brief petrographic descriptions of the samples are given in Table 1. Shear velocities, measured for three basalts and one breccia, were obtained from the same cores as the compressional wave velocities. Ratios of compressional to shear wave velocities $\left(V_{\mathrm{p}} / V_{\mathrm{s}}\right)$, Poissons' ratios $(\sigma)$, bulk moduli $(K)$, shear moduli $(\mu)$, Lames' constants $(\lambda)$, and Young's moduli (E) are also given in Table 1 at selected pressures. The elastic constants were calculated using the equations given by Birch (1961). On the basis of earlier studies, wherein low anistropy for oceanic basalts has been found (e.g., Christensen and
TABLE 1

Velocities, Densities, and Elastic Constants

\begin{tabular}{lcccccccc}
\hline $\begin{array}{c}P \\
(\mathrm{kbar})\end{array}$ & $\begin{array}{c}V_{p} \\
(\mathrm{~km} / \mathrm{sec})\end{array}$ & $\begin{array}{c}V_{S} \\
(\mathrm{~km} / \mathrm{sec})\end{array}$ & $V_{p} / V_{s}$ & $\sigma$ & $\begin{array}{c}\mathrm{K} \\
(\mathrm{Mb})\end{array}$ & $\begin{array}{c}\mu \\
(\mathrm{Mb})\end{array}$ & $\begin{array}{c}\lambda \\
(\mathrm{Mb})\end{array}$ & $\begin{array}{c}\mathrm{E} \\
(\mathrm{Mb})\end{array}$ \\
\hline $43-382-19-4,9-12 \mathrm{~cm}$ & & & & & & & \\
& & & & & & & & \\
0.2 & 3.50 & 1.71 & 2.05 & 0.34 & 0.17 & 0.06 & 0.13 & 0.16 \\
0.4 & 3.54 & 1.81 & 1.96 & 0.32 & 0.17 & 0.07 & 0.13 & 0.18 \\
0.6 & 3.57 & 1.86 & 1.92 & 0.31 & 0.17 & 0.07 & 0.12 & 0.19 \\
0.8 & 3.60 & 1.89 & 1.90 & 0.31 & 0.17 & 0.07 & 0.12 & 0.20 \\
1.0 & 3.62 & 1.91 & 1.90 & 0.31 & 0.17 & 0.08 & 0.12 & 0.20
\end{tabular}

$\rho=2.089 \mathrm{~g} / \mathrm{cc}$.

Description :

$40 \%$ highly altered, reddish brown palagonite and basaltic fragments $(1-2 \mathrm{~mm}$, well sorted by size); $30 \%$ single crystal hornblende (slightly altered), clinopyroxene, olivine, and plagioclase feldspar $(1 \mathrm{~mm}) ; 30 \%$ cement (calcite 10\%, zeolites $20 \%$ ).

$\begin{array}{cc}43-382-25-2,9-11 \\ 0.2 & 2.90 \\ 0.4 & 3.15 \\ 0.6 & 3.26 \\ 0.8 & 3.33 \\ 1.0 & 3.39 \\ 2.0 & 3.56 \\ 4.0 & 3.74\end{array}$

$\rho=1.782 \mathrm{~g} / \mathrm{cc}$.

Description:

$70 \%$ highly altered, reddish brown palagonite and basaltic fragments $(<1 \mathrm{~cm}$, poorly sorted), vesicles filled by calcite, zeolites, or rimmed by a phyllosilicate; $30 \%$ cement (calcite)

\section{$43-384-22-2,97-99 \mathrm{~cm}$}

$\begin{array}{ll}0.2 & 3.80 \\ 0.4 & 3.86 \\ 0.6 & 3.91 \\ 0.8 & 3.96 \\ 1.0 & 4.00 \\ 2.0 & 4.15 \\ 4.0 & 4.38 \\ 6.0 & 4.58\end{array}$

$\rho=2.367 \mathrm{~g} / \mathrm{cc}$.

Description:

Highly weathered porphyritic basalt; $10 \%$ completely altered phenocrysts $(<3 \mathrm{~mm})$ of plagioclase feldspar and pyroxene; $60 \%$ altered groundmass of plagioclase laths and feathery pyroxene; $30 \%$ calcite and chlorite filling vesicles.

$$
\text { 43-385-20, CC (4-7) }
$$

$\begin{array}{ll}0.2 & 4.30 \\ 0.4 & 4.55 \\ 0.6 & 4.71 \\ 0.8 & 4.82 \\ 1.0 & 4.89\end{array}$

$\rho=2.252 \mathrm{~g} / \mathrm{cc}$

Description:

$45 \%$ highly altered, reddish brown palagonite and basaltic fragments $(<5 \mathrm{~mm}$, poorly sorted), vesicles filled by zeolites or calcite, zeolites rim some clasts; $5 \%$ single crystal rimmed pyroxene (up to $2 \mathrm{~mm}$ ); $50 \%$ cement (calcite).

43-385-23-2, $92-95 \mathrm{~cm}$

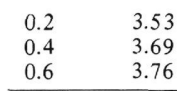




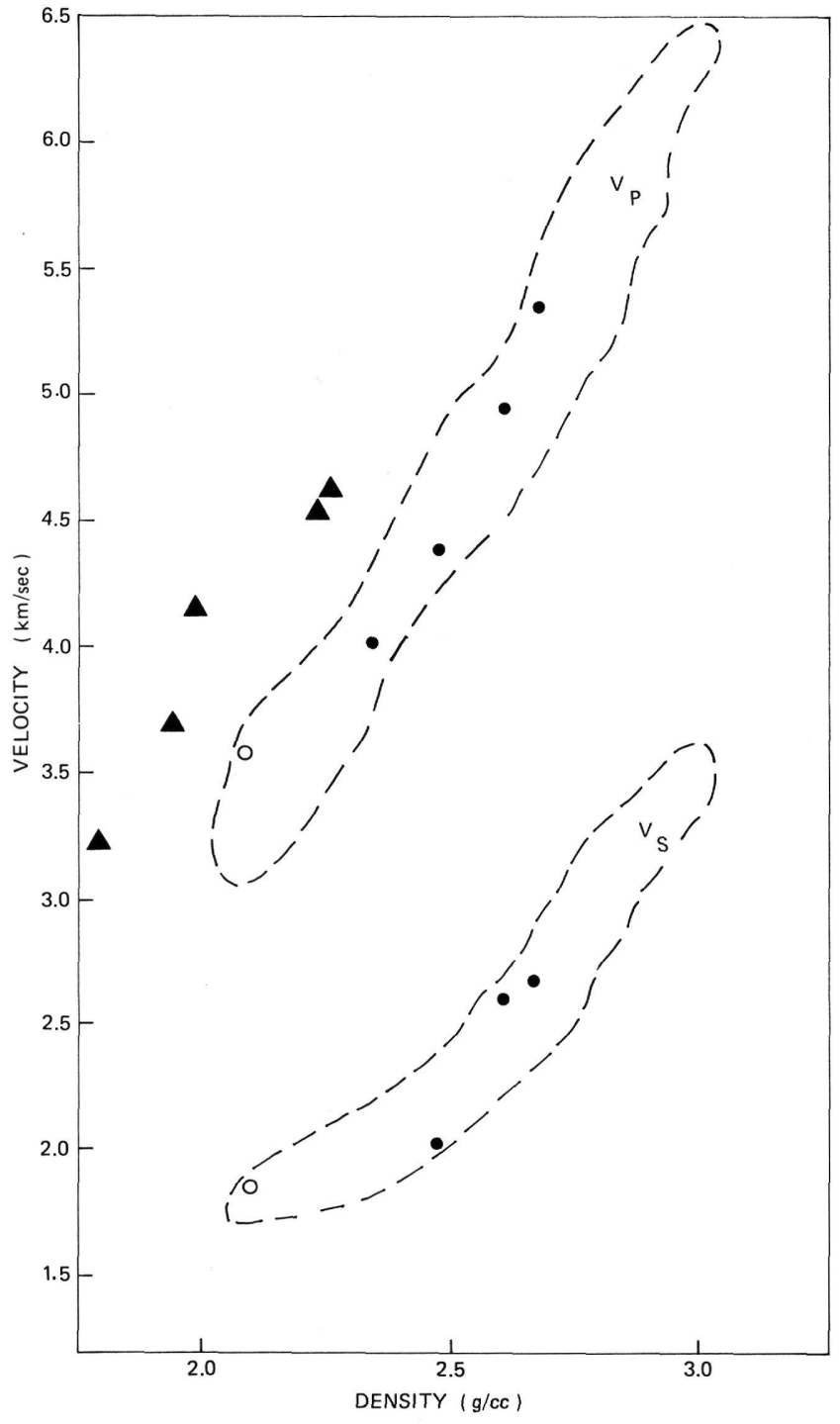

Figure 1. Bulk density versus compressional $\left(V_{p}\right)$ and shear $\left(V_{s}\right)$ wave velocities at $0.4 \mathrm{kbar}$ for basalts (closed circles) and breccias (triangles). The open circle represents Sample 382-19-4, and the dashed lines enclosed previous data for oceanic basalts (Christensen and Salisbury, 1975).

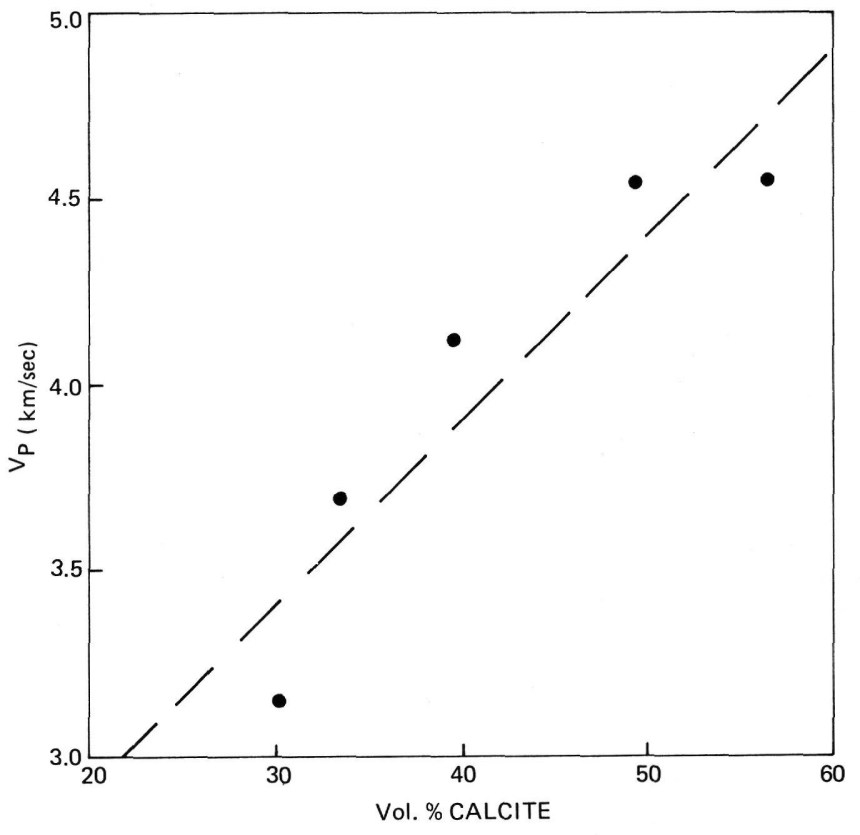

Figure 2. Volume percent calcite versus compressional wave velocity at 0.4 kbar for volcaniclastic breccias. The dashed line represents a least-squares solution of the data $\left(V_{p}=0.05 C+1.91\right.$, where $\mathrm{C}$ is volume \% $\left.\mathrm{CaCO}_{3}\right)$.

\section{REFERENCES}

Barrett, D. L. and Aumento, F., 1970. The Mid-Atlantic Ridge near $45^{\circ}$ N. XI. Seismic velocity, density and layering of the crust: Canadian J. Earth Sci., v. 70, p. 1117-1124.

Birch, F., 1960. The velocity of compressional waves in rocks to 10 kilobars, 1: J. Geophys, Res., v. 65, p. 1083-1102.

1961. The velocity of compressional waves in rocks to 10 kilobars, 2: J. Geophys. Res., v. 66, p. 2199-2224.

Christensen, N. I. and Salisbury, M. H., 1973. Velocities, elastic moduli and weathering-age relations for Pacific Layer 2 basalts: Earth Planet. Sci. Lett., v. 19, p. 461-470. 1975. Structure and constitution of the lower oceanic crust: Rev. Geophys. Space Phys., v. 13, p. 57-86.

Christensen, N. I. and Shaw, G. H., 1970. Elasticity of mafic rocks from the mid-Atlantic ridge: Geophys. J. Roy. Astron. Soc., v. 20, p. 271-284.

Fox, P. J., Schreiber, E., and Peterson, J. J., 1973. The geology of the oceanic crust: compressional wave velocities of oceanic rocks: J. Geophys. Res., v. 78, p. 5155-5172. 